This is the author's final, peer-reviewed manuscript as accepted for publication. The publisher-formatted version may be available through the publisher's web site or your institution's library.

\title{
Long-term nitrogen and tillage effects on soil physical properties under continuous grain sorghum
}

DeAnn R. Presley, Aaron J. Sindelar, Meghan E. Buckley, and David B. Mengel

\section{How to cite this manuscript}

If you make reference to this version of the manuscript, use the following information:

Presley, D. R., Sindelar, A. J., Buckley, M. E., \& Mengel, D. B. (2012). Long-term nitrogen and tillage effects on soil physical properties under continuous grain sorghum. Retrieved from http://krex.ksu.edu

\section{Published Version Information}

Citation: Presley, D. R., Sindelar, A. J., Buckley, M. E., \& Mengel, D. B. (2012). Longterm nitrogen and tillage effects on soil physical properties under continuous grain sorghum. Agronomy Journal, 104(3), 749-755.

Copyright: Copyright $\odot 2012$ by the American Society of Agronomy

Digital Object Identifier (DOI): doi:10.2134/agronj2011.0311

Publisher's Link: https://www.agronomy.org/publications/aj/articles/104/3/749

This item was retrieved from the K-State Research Exchange (K-REx), the institutional repository of Kansas State University. K-REx is available at http://krex.ksu.edu 


\title{
Long-term nitrogen and tillage effects on soil physical properties under
} continuous grain sorghum

\begin{abstract}
Grain sorghum [Sorghum bicolor (L.) Moench] is an important grain crop grown in both highly productive and marginal areas in the central Great Plains because of the crop's ability to utilize the erratic precipitation observed in this region. More effective capture and storage of this limited rainfall is needed to improve the productivity and profitability of dryland agriculture. The objective of this study was to determine the effects of long-term tillage and nitrogen $(\mathrm{N})$ fertilization on soil physical and hydraulic properties after long-term continuous grain sorghum production. Variables included conventional tillage (CT) and no-till (NT) and four rates of N fertilizer. Selected soil quality indicators included soil organic carbon (SOC), bulk density (BD), wet aggregate stability (WAS), and ponded infiltration. No-till accumulated more SOC in the surface 0-5 cm, and was less dense at all depths than CT. When tillage was compared across all $\mathrm{N}$ rates, NT contained 30\% greater SOC than $\mathrm{CT}$ at the $0-5 \mathrm{~cm}$. Mean weight diameter (MWD) was larger with increasing $\mathrm{N}$ fertilization and eliminating tillage. Ponded infiltration rates were greatest for the high $\mathrm{N}$ fertilization rate under $\mathrm{NT}$, and lowest for the $0 \mathrm{Kg} \mathrm{N}^{-1}$ rate under $\mathrm{CT}$. In this long-term grain sorghum system, increasing $\mathrm{N}$ fertilization rate and NT both positively affected soil physical properties. These improvements in hydraulic properties will aid in more effectively capturing unpredictable precipitation, and further underscore the utility of NT management practices for the central Great Plains region.
\end{abstract}


Abbreviations: $\mathrm{BD}$, bulk density; $\mathrm{CT}$, conventional tillage; MWD, mean weight diameter; N, nitrogen; NT, no-till; SOC, organic carbon; WAS, wet aggregate stability; WSA, water-stable aggregates.

\section{INTRODUCTION}

Tillage practices and $\mathrm{N}$ fertilization rates can potentially affect soil physical properties. In continuous sorghum, tillage is commonly used for stover and weed management, but NT practices have increased recently in the central Great Plains because of agronomic and environmental advantages including increased stored water, decreased wind and water erosion susceptibility, increased C storage, and improvements in soil physical properties (Reicosky and Saxton, 2007; Blanco and Lal, 2008). As a result of these advantages, $35 \%$ of grain sorghum planted in Kansas was planted under NT in 2004, compared with 4\% in 1989 (CTIC, 2004).

Previous studies have documented the effects of management practices, including tillage and $\mathrm{N}$ fertilization rates, on Great Plains SOC levels. Halvorson et al. (2000) observed increasing SOC as fertilization rates increased under NT in eastern Colorado. McVay et al. (2006) summarized five long-term studies in Kansas, one consisting of continuous sorghum, and observed that decreased tillage, increased fertilization, and crop rotations that included at least one cereal crop in the rotation increased SOC at the $0-5 \mathrm{~cm}$. Guzman et al. (2006) observed 2.7 $\mathrm{Mg} \mathrm{ha}^{-1}$ more SOC in the surface $7.5 \mathrm{~cm}$ in NT than CT under long-term continuous sorghum at Manhattan, KS. The effects of tillage on SOC dynamics are well documented across several environments (Tiessen et al., 1982; Odell et al., 1984; Mikha et al., 2006). West and Post (2002) summarized results from numerous tillage and rotation experiments throughout the U.S. and concluded that switching from CT to NT stores an average $57 \pm 14 \mathrm{~g} \mathrm{C} \mathrm{m}^{-2} \mathrm{yr}^{-1}$ [except wheat 
45 (Triticum aestivum L.)-fallow systems]. Soil OC storage in the surface layer is commonly greater under NT than CT (West and Post, 2002), but the effect of tillage practices on SOC storage

47 beneath the surface layer (generally greater than 5 to $7.5 \mathrm{~cm}$ ) often varies across experiments. In

48 the Great Plains region, tillage generally does not affect SOC at any depth interval other than the surface (McVay et al., 2006; Mikha et al., 2006).In a long-term experiment on a Vertisol in a

50 sub-tropic environment in Australia, Saffigna et al. (1989) showed that SOC in the surface $10 \mathrm{~cm}$

51 in a continuous sorghum system was 7\% greater in NT than CT, mainly because of slower

52 decomposition rates in NT.

Changes in soil physical properties such as BD and WAS are affected by management

54 practices, especially tillage (Pikul et al., 2006), and WAS is one of the most sensitive variables to

55 the reduction of tillage (Blanco and Lal, 2008; Stone and Schlegel, 2010). No-till generally has

56 been observed to produce more (and larger) WSA compared with more intensive tillage methods

57 (Angers et al., 1993; McVay et al., 2006), whereas effects on BD are less predictable and

58 dependent on the time of year and conditions when sampled (Pikul et al., 2006; Strudley et al.,

59 2008; Stone and Schlegel, 2010). Six et al. (2000) and Blanco-Canqui et al. (2009) observed an

60 increase in the mass of macroaggregates and a decrease in microaggregates in NT compared with

61 CT. Blanco-Canqui et al. (2009) also found that NT macroaggregates were less susceptible to

62 water erosion because they required greater kinetic energy from raindrops for destruction and the

63 aggregates were less wettable compared with aggregates sampled from CT treatments.

Wet aggregate stability also has been shown to be closely associated with soil organic

65 matter (Angers et al., 1992) because organic matter serves as a binding agent for soil aggregates

66 (Tisdall and Oades, 1982). Tisdall and Oades (1982), Elliot (1986), and Angers et al. (1992) all

67 observed decreasing soil organic matter with declining WAS. This can be attributed to protection 
of SOC from microbial decomposition through sorption to clay minerals (Hassink et al., 1993) and encapsulation within soil aggregates (Tisdall and Oades, 1982). Soil tilth also improves under NT because well aggregated soils are less subject to hardening upon drying than poorly aggregated soils (Karunatilake and van Es, 2002).

Improving aggregation through management can also improve infiltration and efficient water capture, which is critical in water-limited regions such as the central Great Plains. Soil water storage has been found to increase under NT in wheat and grain sorghum regardless of crop rotation (Norwood, 1994; Peterson et al., 1996). The properties of infiltration and WAS are also often strongly related (Boyle et al., 1989; Le Bissonnais and Arrouays, 1997) and affected similarly by management practices (Stone and Schlegel, 2010). Because of these improvements in soil aggregation and in the presence of raindrop-impact-absorbing stover, more rapid infiltration rates have been observed in NT treatments compared with CT in long-term tillage experiments in the Great Plains (Stone and Schlegel, 2010). However, under some moisturelimiting dryland environments in the Great Plains, the opposite has been observed; this has been attributed to the fact that dryland crop stover production can often be quite low (Baumhardt and Jones, 2002; Pikul et al., 2006). Armand et al. (2009) summarized several tillage comparison studies and concluded that greater runoff has been observed occasionally in NT when stover was insufficient to protect the soil surface from structural degradation during rainfall. Even in studies where NT generated more runoff than CT, erosion rates and sediment loss were lower for NT than CT (Buckley-Zeimen et al., 2006; Armand et al., 2009). properties, namely infiltration, depends on the productivity of the entire system. Further research is warranted regarding the interactions of these management practices on soil physical properties, 
91 specifically in a region where grain sorghum is a major crop. These management practices,

92 especially tillage and $\mathrm{N}$ fertilization, are decisions that can greatly affect success of the crop,

93 particularly in marginal areas. Long-term effects of continuous grain sorghum and varying $\mathrm{N}$

94 rates on soil physical properties are not sufficiently documented, especially in Kansas, where a

95 significant proportion of U.S. sorghum production occurs. Research on tillage and N fertilization

96 in the Midwest are more common for continuous corn (Zea mays L.) rotations (Blevins et al.,

97 1983; Halvorson et al., 2002), but less frequent for continuous sorghum, thus warranting further

98 investigation. Therefore, the objective of this study was to quantify effects of tillage and $\mathrm{N}$

99 fertilization on soil physical and hydraulic properties, including SOC, BD, WAS, and ponded

100 infiltration after 26 years of continuous grain sorghum.

101

\section{MATERIALS AND METHODS}

\section{Site and Treatment Description}

Field research was conducted on a Smolan silty clay loam soil [fine, smectitic, mesic

105 Pachic Argiustoll (Soil Survey Staff)] on 3\% slope (land capability class 2e) at the Kansas State

106 University North Agronomy research farm in Manhattan, KS (39 $11^{\prime} \mathrm{N}, 96^{\circ} 35^{\prime}$ W), which

107 receives an average annual precipitation of approximately $830 \mathrm{~mm}$ (KSU Weather Data Library, 108 2010).

The experiment was organized as a split-plot design with three replications, where tillage

110 served as the whole plot and $\mathrm{N}$ fertilization rate served as the subplot. Two tillage methods, CT

111 and NT, were established in 1982 on plots $6.1 \mathrm{~m}$ wide by $9.1 \mathrm{~m}$ long. Conventional tillage

112 consisted of one chisel operation in the fall and three disking operations in the spring. In 2000, 
113 CT was reduced to one chisel operation and one sweep cultivation in the spring. Depth of tillage

114 ranged from 10 to $15 \mathrm{~cm}$. Sorghum was grown annually from 1982 through 2007. In 2008,

115 soybean [(Glycine max (L.) Merr.] was planted to transition to a winter wheat-sorghum-soybean

116 rotation. No $\mathrm{N}$ fertilizer was applied to the 2008 soybean crop. Although measurements were

117 taken during the 2008 soybean growing season, we believe the soil properties were

118 predominantly a result of the long-term management under continuous sorghum from 1982

119 through 2007.

Throughout the experiment, treatment $\mathrm{N}$ rates remained unchanged at $0,34,67$, and 135

$121 \mathrm{~kg} \mathrm{~N}$ ha-1, but fertilizer sources and placement varied. Nitrogen rates were $0,34,67$, and $135 \mathrm{~kg}$

$122 \mathrm{~N} \mathrm{ha}^{-1}$ throughout the entire duration of the study. When the study was initiated, ammonium

123 nitrate (33-0-0) and urea (45-0-0) were used as $\mathrm{N}$ source treatments and were applied via

124 broadcast or knife application, which served as the placement variables. In 1995, this application

125 method was discontinued, a urease-based $\mathrm{N}$ stabilizer was added to the $\mathrm{N}$ source treatments, and

126 all $\mathrm{N}$ fertilizer was applied through broadcast (with incorporation in CT plots) for the remaining

127 duration of the study. Placement was discontinued because of work by Matowo et al. (1999),

128 who observed that placement had little effect on chemical soil properties. In 2000 , the $\mathrm{N}$

129 stabilizer was replaced by controlled-release urea. In 2001, lime was broadcast applied at 2230

$130 \mathrm{~kg} \mathrm{ha}^{-1}$ to reduce soil acidity.

Physical and hydraulic soil properties include SOC, BD, WSA, and ponded infiltration.

134 All $\mathrm{N}$ rate treatments were sampled for SOC and BD. For WAS and infiltration, only the extreme 
1350 and $135 \mathrm{~kg} \mathrm{~N} \mathrm{ha}^{-1}$ treatments were sampled due to the time intensive nature of these 136 experiments. 2008. Soil was sampled to a depth of $15 \mathrm{~cm}$, and samples were separated into 5-cm-depth increments. Bulk density was determined by the core method proposed by Grossman and Reinsch (2002) by using 5-cm diameter $\times 15$-cm length cores segmented into three 5 -cm-long 141 cores and replicated three times per plot. Three cores of the dimensions similar to BD were also 142 sampled, homogenized into a composite sample for each depth, and split into two subsamples. 143 One subsample was analyzed for SOC by dry combustion through the method proposed by 144 Nelson and Sommers (1996) with a LECO CN-2000 (LECO Corporation, St. Joseph, MI). 145 Particle size distribution was determined from the remaining subsample (surface $0-5 \mathrm{~cm}$ only) by 146 pulverizing the soil with a wooden rolling pin to pass through a sieve with 2-mm openings, and 147 using the pipette method 3A1 (Soil Survey Staff, 1996). 149 shovel in three different locations in the plot and compositing samples in a breathable cloth bag. 150 Samples were air-dried and manually processed through sieves to obtain aggregates sized 151 between 4.75 and $8 \mathrm{~mm}$. Samples were then processed through a wet method adapted from 152 Kemper and Rosenau (1986) method; samples were immersed in water for 10 min and agitated 153 for $10 \mathrm{~min}$ following this period. Vertical displacement was $37 \mathrm{~mm}$ at 30 cycles $\mathrm{min}^{-1}$. Sieve 154 sizes were $212,500,1000,2000$, and $4750 \mu \mathrm{m}$. Following agitation, each size fraction was oven155 dried at $105^{\circ} \mathrm{C}$, weighed, and expressed as a percentage of the total soil after correction for sand 156 and coarse fragments. Mean weight diameter for WSA was then calculated according to Kemper 157 and Rosenau (1986). 


\section{Infiltration methods}

Ponded, steady-state infiltration was determined in September 2008 from triplicate

161

162

163

164

165

166

167 double-ring infiltration measurements in each plot (Reynolds et al., 2002). Rings were circular (30 and $61 \mathrm{~cm}$ diameter) and made from 0.3-cm-thick steel that was $30 \mathrm{~cm}$ tall. Rings were driven to a depth of $7.6 \mathrm{~cm}$ in non-trafficked interrows. Rings were filled with water, refilled approximately12 $\mathrm{hr}$ later, and the measurement period was initiated. Water depth measurements were made from the water height in the inner ring at $1.5-\mathrm{hr}$ intervals until steady-state conditions were confirmed, which was up to a 9-hr period for most treatments. Throughout the measurement period, ponding was maintained from 10 to $15 \mathrm{~cm}$.

\section{Statistical Analysis}

Data were analyzed with SAS as a split-plot arrangement in a randomized complete design with three replications by using the MIXED procedure in SAS with tillage as the main plot and $\mathrm{N}$ fertilization rate as the subplot (SAS Institute, 2004). Tillage, $\mathrm{N}$ fertilization rate, and their interactions were considered fixed effects, while block and its interactions were random. Mean separations were performed if the F-tests for main treatment effects or their interactions were significant using Fisher's protected LSD test $(\alpha=0.05)$. Relationships between select soil properties, including the $0-10 \mathrm{~cm}$ SOC and MWD, as well as MWD and 0-5 cm BD were also

77 investigated through linear regression using the MIXED procedure in SAS $(\alpha=0.05)$. 

showed that the surface $0-5 \mathrm{~cm}$ soil texture was uniform across the experimental site, because all plots sampled were a silty clay loam with an average of $7.6 \%( \pm 1.1 \%$ standard deviation $)$ sand, 183 $64.2 \%( \pm 2.0 \%)$ silt, and $28.2 \%( \pm 1.3 \%)$ clay. The effects of $\mathrm{N}$ rate and tillage on SOC varied at each depth $(\alpha=0.05$; Table 1$)$. In the $0-5-\mathrm{cm}$ and 5-10 $\mathrm{cm}$ depths within NT, an increase in N fertilization rate generally led to higher SOC content, whereas the effect of $\mathrm{N}$ fertilization rate was less consistent within CT (Table 2). Within the 10-15-cm depth, $\mathrm{N}$ rates did not differ under 187 either tillage method. For total SOC, NT was $10 \%$ greater than CT (34.9 $\mathrm{Mg} \mathrm{ha}^{-1}$ and $31.7 \mathrm{Mg}$ $188 \mathrm{ha}^{-1}$ for NT and CT, respectively), which was primarily driven by $30 \%$ greater SOC in the $0-5$ cm layer. These findings are consistent with other studies in the region (McVay et al., 2006; Mihka et al., 2006). When total SOC was averaged across tillage treatments to examine the overall effect of $\mathrm{N}$ rate, the 67 and $135 \mathrm{~kg} \mathrm{~N} \mathrm{ha}^{-1}$ rates produced the highest total SOC (34.0 and 34.1 $\mathrm{Mg} \mathrm{ha}^{-1}$, respectively), whereas the 0 and $34 \mathrm{~kg} \mathrm{~N}$ ha $^{-1}$ rates were the lowest (32.6 and 32.0 $193 \mathrm{Mg} \mathrm{ha}^{-1}$, respectively). In our study, the $0-5 \mathrm{~cm}$ SOC was affected by both tillage and $\mathrm{N}$ rate, which may be 195 attributed to the decreased disturbance in the NT treatment (McVay et al., 2006), slower 196 decomposition of stover in NT (Saffigna, 1989), and greater biomass returns to the soil surface 197 with higher $\mathrm{N}$ rates (Halvorson et al., 2000). In a study by Mihka et al. (2006) that examined 198 crop rotation effects on soil properties, increases in SOC content were attributed to greater 199 annualized returns of crop stover to the soil. Previous yield data collected by Guzman et al.

200 (2006) in the same plots as our study observed that grain increased with increasing $\mathrm{N}$ 
$202 \mathrm{ha}^{-1}$, and $6260 \mathrm{~kg} \mathrm{ha}^{-1}$ were observed for the $0,34,67$, and $135 \mathrm{~kg} \mathrm{~N}^{-1}$ rates, respectively.

203 Because grain yields increased with each subsequent $\mathrm{N}$ fertilization rate, the biomass yield would

204 be expected to increase assuming harvest index values among treatments did not significantly

205 differ.

206

207

208

209

210

211

212

213

214

215

216

217

218

219

220

221

222

223

Bulk density was affected by tillage at all measured depths, but was affected only by $\mathrm{N}$ rate in the surface $5 \mathrm{~cm}$ (Table 1). Greater variation between treatments was observed in tillage than $\mathrm{N}$ fertilization, suggesting that the tillage method may have a greater influence on $\mathrm{BD}$. At all depths, BD was greater for CT than NT (Table 3). When averaged across N rates, BD under CT was greater than NT by $0.10 \mathrm{Mg} \mathrm{m}^{-3}$ in the $0-5 \mathrm{~cm}$ and by 0.08 and $0.07 \mathrm{Mg} \mathrm{m}^{-3}$ in the $5-10$ and 10-15-cm depths, respectively. Furthermore, BD in CT averaged across $\mathrm{N}$ rates for both the 5-10 and 10-15-cm depths exceed 1.50 $\mathrm{Mg} \mathrm{m}^{-3}$, which is the threshold BD that restricts proliferation of plant roots for a silty clay loam-textured soil (USDA-NRCS, 1996). Our results contrast those of McVay et al. (2006), who observed that BD values were minimally affected by tillage below the surface $0-3 \mathrm{~cm}$, and that BD was often higher for NT than $\mathrm{CT}$, however, it is important to note that McVay et al. (2006) sampled their sites in the fall after the tillage passes had recently occurred. Inconsistent effects of tillage on BD have been observed in numerous experiments and were recently summarized by Strudley et al. (2008), who concluded that variations in space and time can make treatment effects undetectable.

Nitrogen rate and tillage produced varying effects on WSA (Table 1, Fig. 1). For all WSA classes, the value after the $>$ symbol indicates the smallest diameter of aggregates collected in a size range, and that the upper limit is the next largest sieve size; e.g., $>212 \mu$ means that the aggregates collected on this sieve were between 500 and $212 \mu \mathrm{m}$ in diameter. In NT, more 
$224>212 \mu \mathrm{m}$ WSA were found for the $135 \mathrm{~kg} \mathrm{~N} \mathrm{ha}^{-1}$ fertilization rate compared with the $0 \mathrm{~kg} \mathrm{~N} \mathrm{ha}^{-1}$ 225 fertilization rate.

Nitrogen fertilization rate did not influence $>212 \mu \mathrm{m}$ WSA under CT. When tillage

227 methods were compared, more $>212 \mu \mathrm{m}$ WSA were found in CT than NT within the $0 \mathrm{~kg} \mathrm{~N} \mathrm{ha}^{-1}$

228 fertilization rate. When $135 \mathrm{~kg} \mathrm{~N} \mathrm{ha}^{-1}$ was applied, tillage did not influence $>212 \mu \mathrm{m}$ WSA. No

229 differences were measured between either $\mathrm{N}$ rates or tillage method for the $>500 \mu \mathrm{m}$ size

230 fraction. For the $>1000 \mu \mathrm{m}$-sized fraction, no differences existed within $\mathrm{N}$ rates for either NT or

231 CT. At both $\mathrm{N}$ rates, more $>1000 \mu \mathrm{m}$ aggregates were found for NT than CT.

For $>2000 \mu \mathrm{m} \mathrm{WSA}$, the effects of both tillage and $\mathrm{N}$ fertilization rate were significant

233 (Table 1), with more aggregate mass observed for both NT and the $135 \mathrm{~kg} \mathrm{~N} \mathrm{ha}^{-1}$ fertilization

234 rate than $\mathrm{CT}$ and the $0 \mathrm{~kg} \mathrm{~N} \mathrm{ha}^{-1}$ fertilization rate, respectively (Fig. 1). In the $>4750 \mu \mathrm{m}$ fraction,

235 more aggregate mass was measured for the $135 \mathrm{~kg} \mathrm{~N} \mathrm{ha}^{-1}$ fertilization rate within $\mathrm{CT}$, but $\mathrm{N}$ rates

236 within NT did not differ. More aggregate mass was also measured for NT than CT for both N

237 rates. The MWD was greater for the $135 \mathrm{~kg} \mathrm{~N} \mathrm{ha}^{-1}$ fertilization rate than for the $0 \mathrm{~kg} \mathrm{~N} \mathrm{ha}^{-1}$

238 fertilization rate within each tillage practice, and was greater for NT than CT at each of the two

$239 \mathrm{~N}$ fertilization rates.

The association between SOC and MWD was examined by regression, and a positive

241 linear relationship was observed $\left(\mathrm{R}^{2}=0.62\right.$; Fig. $\left.2 \mathrm{~A}\right)$. Based on the regression, MWD is predicted

242 to increase by $0.15 \mathrm{~mm}$ for each $\mathrm{Mg} \mathrm{ha}^{-1}$ increase in SOC. Greater MWD and greater mass of the

$243>1000,>2000$, and $>4750 \mu \mathrm{m}$-sized aggregates for the high $\mathrm{N}$ rate are probably because of

244 greater grain yields and greater SOC content, likely because more stover would have been

245 returned to the soil surface to build both SOC and form/protect larger WSA (Tisdall and Oades, 
246 1982; Angers et al., 1992; Blanco-Canqui et al., 2009; Mikha et al., 2010). The association

247 between the surface $5 \mathrm{~cm}$ MWD and BD also was examined by regression, and a negative linear

248 relationship was observed $\left(\mathrm{R}^{2}=0.82\right.$; Fig. $\left.2 \mathrm{~B}\right)$, suggesting that as water-stable aggregation

249 increases, BD decreases, resulting in an increased total porosity fraction. Based on the

250 regression, BD is predicted to decrease by $0.015 \mathrm{Mg} \mathrm{m}^{-3}$ for every $0.1 \mathrm{~mm}$ increase in MWD.

251 Less soil disturbance by tillage in the NT soil may explain the presence of larger aggregates and 252 a greater MWD as well as reduced BD for the NT treatments (Pikul et al., 2006; McVay et al., 253 2006).

Differences in infiltration were observed between $\mathrm{N}$ fertilization rates, although the 255 response to $\mathrm{N}$ differed between tillage methods (Table 1). Under NT, a more rapid infiltration 256 rate $\left(1.26 \mathrm{~cm} \mathrm{hr}^{-1}\right)$ was observed when $135 \mathrm{~kg} \mathrm{~N} \mathrm{ha}^{-1}$ was applied than when the $0 \mathrm{~kg} \mathrm{ha}^{-1} \mathrm{~N}$ 257 fertilization rate $\left(0.36 \mathrm{~cm} \mathrm{hr}^{-1}\right)$ was used, which represented a $245 \%$ increase because of the 258 long-term application of $\mathrm{N}$ within the NT treatment (Fig. 3). Nitrogen rate had no effect on 259 ponded infiltration under CT, and tillage produced no effect on ponded infiltration between 260 tillage methods at the either fertilization rate. Ponded infiltration may not have been strongly 261 affected by tillage or $\mathrm{N}$ fertilization in this study because of spatial variability as seen by Neurath 262 et al. (2005). No linear relationships between ponded infiltration and either the 0-5-cm SOC $263(p=0.66), 0-5-\mathrm{cm} \mathrm{BD}(\mathrm{p}=0.34)$, or MWD $(\mathrm{p}=0.53)$ were observed in regression analyses (data not 264 shown); however, infiltration often correlates strongly to WAS (Boyle et al., 1989; Le 265 Bissonnais, et al., 1997) and affected similarly by management practices (Stone and Schlegel, 266 2010). Because of greater soil aggregation and lower surface BD, more rapid infiltration rates are 267 common in long-term NT (Stone and Schlegel, 2010). Although no significant correlation was 
measured, the greatest values of 0-5 $\mathrm{cm}$ SOC and MWD and lowest 0-5 $\mathrm{cm}$ BD corresponded with the NT-135 $\mathrm{kg} \mathrm{N} \mathrm{ha}^{-1}$ treatment, which also exhibited the greatest ponded infiltration rate.

\section{CONCLUSIONS}

Differences in soil physical properties were quantified $26 \mathrm{yr}$ after the establishment of tillage (NT and CT) and N fertilization rates within a continuous grain sorghum experiment. Notill and increasing $\mathrm{N}$ fertilization both positively affected individual soil and hydraulic properties compared with CT. No-till treatments contained $30 \%$ more SOC in the $0-5 \mathrm{~cm}$ than CT and were less dense in the $0-5 \mathrm{~cm}$. Increasing rates of $\mathrm{N}$ fertilization increased SOC but had no effect on BD. Averaged over all N rates, NT had lower BD values at all three depths. Wet aggregate mass was greater with increasing $\mathrm{N}$ fertilization rate for both $\mathrm{CT}$ and $\mathrm{NT}$, and MWD was positively correlated with SOC. Ponded infiltration rate increased $245 \%$ with the $135 \mathrm{~kg} \mathrm{~N}^{-1}$ fertilization rate than with the $0 \mathrm{~kg} \mathrm{~N} \mathrm{ha}^{-1}$ rate under $\mathrm{NT}$. There were no differences between $\mathrm{N}$ rate under CT, nor were there any differences between NT and CT when comparing between N rates. In conclusion, desirable physical soil properties that contribute to greater infiltration correspond to soils managed under NT and high fertilization. Our results suggest that management practices to promote greater biomass and reduced soil disturbance will increase SOC, WSA, and consequently infiltration for improved crop water management. 
Angers, D.A., A. Pesant, and J. Vigneaux. 1992. Early cropping-induced changes in soil aggregation, organic matter, and microbial biomass. Soil Sci. Soc. Am. J. 56:115-119.

Angers, D.A., N. Samson, and A. Légère. 1993. Early changes in water-stable aggregation induced by rotation and tillage in a soil under barley production. Can. J. Soil Sci. 73:5159.

Armand, R., C. Bockstaller, A.-V. Auzet, and P. Van Dijk. 2009. Runoff generation related to intra-field soil surface characteristics variability: Application to conservation tillage context. Soil Tillage Res. 102:27-37.

Baumhardt, R.L., and O.R. Jones. 2002. Residue management and tillage effects on soil-water storage and grain yield of dryland wheat and sorghum for a clay loam in Texas. Soil Tillage Res. 68:71-82.

Blanco, H., and R. Lal. 2008. Principles of soil conservation and management. Springer Publ. Co., New York.

Blanco-Canqui, H, M.M. Mikha, J.G. Benjamin, L.R. Stone, A.J. Schlegel, D.J. Lyon, M.F. Vigil, and P.W. Stahlman. 2009. Regional study of no-till impacts on near-surface aggregate properties that influence soil erodibility. Soil Sci. Soc. Am. J. 73: 1361-1368.

Blevins, R.L., G.W, Thomas, M.S. Smith, W.W, Frye, and P.L. Cornelius. 1983. Changes in soil properties after 10 years of continuous non-tilled and conventionally tilled corn. Soil Tillage Res. 3:135-146.

Boyle, M., W.T. Frankenberger, Jr., and L.H. Stolzy. 1989. The influence of organic matter on soil aggregation and water infiltration. J. Prod. Agric. 2:290-299. 
Buckley-Zeimen, M., K.A. Janssen, D.W. Sweeney, G.M. Pierzynski, K.R. Mankin, D.L. Devlin, D.L. Regehr, M.R. Langemeier, and K.A. McVay. 2006. Combining management practices to reduce sediment, nutrients, and herbicides in runoff. J. Soil Water. Cons. 61:258-267.

Conservation Technology Information Center. 2004. Crop residue management survey. West Lafayette, IN.

Elliot, E.T. 1986. Aggregate structure and carbon, nitrogen, and phosphorus in native and cultivated soils. Soil Sci. Soc. Am. J. 50:627-633.

Grossman, R.B., and T.G. Reinsch. 2002. Bulk density and linear extensibility. p. 201-228. In J.H. Dane et al. (ed.) Methods of soil analysis. Part 4. SSSA Book Ser. 5. SSSA, Madison, WI.

Guzman, J.G., C.B. Godsey, G.M. Pierzynski, D.A. Whitney, and R.E. Lamond. 2006. Effects of tillage and nitrogen management on soil chemical and physical properties after 23 years of continuous sorghum. Soil Tillage Res. 91:199-206.

Halvorson, A.D., C.A. Reule, and L.S. Murphy. 2000. No-tillage and N fertilization enhance soil carbon sequestration. Fluid J. 8:8-11.

Halvorson, A.D., G.A. Peterson, and C.A. Reule. 2002. Tillage system and crop rotation effects on dryland crop yields and soil carbon in the central Great Plains. Agron. J. 94:14291436. 
Hassink, J., L.A. Bouman, K.B. Zwart, J. Bloem, and L. Brussaard. 1993. Relationships between soil texture, physical protection of organic matter, soil biota, and $\mathrm{C}$ and $\mathrm{N}$ mineralization in grassland soils. Geoderma 57:105-128.

Kansas State University Weather Data Library. 2010. Kansas weather \& ET data. [Online] Available at http://wdl.agron.ksu.edu/ (verified 24 Feb., 2011).

Karunatilake, U.P., and H.M. van Es. 2002. Rainfall and tillage effects on soil structure after alfalfa conversion to maize on a clay loam soil in New York. Soil Tillage Res. 67:135146.

Kemper, W.D., and R.C. Rosenau. 1986. Aggregate stability and size distribution. p. 425-442 In A. Klute (ed.) Methods of soil analysis. Part 1. 2nd ed. Agron. Monogr. 9. ASA and SSSA, Madison, WI.

Le Bissonnais, Y. and D. Arrouays. (1997). Aggregate stability and assessment of soil crustability and erodibility. 2 Application to humic loamy soils with various organic carbon contents. European J. Soil Sci. 48:39-48.

Matowo, P.R., G.M. Pierzynski, D.A. Whitney, and R.E. Lamond. 1999. Soil chemical properties as influenced by tillage and nitrogen source, placement, and rates after 10 years of continuous sorghum. Soil Tillage Res. 50:11-119.

McVay, K.A., J.A. Budde, K. Fabrizzi, M.M. Mikha, C.W. Rice, A.J. Schlegel, D.E. Peterson, D.W. Sweeney, and C. Thompson. 2006. Management effects on soil physical properties in long-term tillage studies in Kansas. Soil Sci. Soc. Am. J. 70:434-438. 
Mikha, M.M., J.G. Benjamin, M.F. Vigil, and D.C. Nelson. 2010. Cropping intensity impacts on soil aggregation and Carbon sequestration in the Great Plains. Soil Soc. Am. J. 74:17121919.

Mikha, M.M., M.F. Vigil, M.A. Liebig, R.A. Bowman, B. McConkey, and E.J. Deibert. 2006. Cropping systems influences on soil chemical properties and soil quality in the Great Plains. Renewable Agri. Food Syst. 21:26-35.

National Agricultural Statistics Service. 2009. Crop production 2009 summary. Available at http://usda.mannlib.cornell.edu/usda/current/CropProdSu/CropProdSu-01-12-2009.pdf. (accessed 17 March 2009; 22 Dec. 2009).

Nelson, D.W., and L.E. Sommers. 1996. Total carbon, organic carbon, and organic matter. p. 961-1010. In Weaver, et al. (ed), Methods of Soil Analysis. Part 3. Agron. Monogr. 9. ASA and SSSA, Madison, WI.

Neurath, S.K., A.M. Sadeghi, A. Shirmohammadi, A.R. Isenee, K.A. Sefton, and A. Torrents. 2005. Spatial variability in the upper soil layers of a no-till field using a small-scale dye experiment. Soil Sci. 170:881-891.

Norwood, C. 1994. Profile water distribution and grain yield as affected by cropping system and tillage. Agron. J. 86:558-563.

Odell, R.T., S.W. Melsted, and W.M. Walker. 1984. Changes in organic carbon and nitrogen of Morrow Plot soils under treatments, 1904-1973. Soil Sci. 137:160-171.

Peterson, G.A., A.J. Schlegel, D.L. Tanaka, and O.R. Jones. 1996. Precipitation use efficiency as affected by cropping and tillage systems. J. Prod. Agric. 9:180-186. 
Pikul, J.L., R.C. Schwarz, J.G. Benjamin, J.G., R.L. Baumhardt, and S. Merrill. 2006. Cropping systems influences on soil physical properties in the Great Plains. Renewable Agric. Food Syst. 21:15-25.

Reicosky, D.C., and K.E. Saxton. 2007. The benefits of no-tillage. p. 11-20 In: C.J. Baker and K.E. Saxton (Ed.) No-tillage seeding in conservation agriculture. Food and Agriculture Organization of the United Nations, Rome.

Reynolds, W.D., D.E. Elrick, and E.G. Youngs. 2002. Single-ring and double- or concentricring infiltrometers. p. 821-826 In J. Dane and G. Topp, (Ed.) Methods of Soil Analysis, Part 4, Physical Methods. SSSA Book Series No. 5, Madison, WI.

SAS Institute. 2004. Release 9.1.3 ed. SAS Institute Inc., Cary, NC.

Saffigna, P.G., D.S. Powlson, P.C. Brookes, and G.W. Thomas. 1989. Influence of sorghum and tillage on soil organic matter and soil microbial biomass in an Australian vertisol. Soil Biol. Biochem. 21:759-765.

Six, J., K. Paustian, E.T. Elliott, and C. Combrink. 2000. Soil structure and organic matter: I. distribution of aggregate-size classes and aggregate-associated carbon. Soil Sci. Soc. Am. J. 64:681-689.

Soil Survey Laboratory Staff. 1996. Soil survey laboratory methods manual. Soil Survey Investigation Report No. 42 version 3.0. National Soil Survey Center, Lincoln.

Soil Survey Staff, Natural Resources Conservation Service, United States Department of Agriculture. Web Soil Survey [Online]. Available at http://websoilsurvey.nrcs.usda.gov/. (accessed 11 Dec. 2009, verified 10 Aug. 2011). 
390 Stone, L.R., and A.J. Schlegel. 2010. Tillage and crop rotation phase effects on soil physical 391 properties in the west-central Great Plains. Agron. J. 102:483-491.

392 Strudley., M.W., T.R. Green, and J.C. Ascough II. 2008. Tillage effects on soil hydraulic properties in space and time: State of the science. Soil Tillage Res. 99:4-48.

394 Tiessen, H. W.J.B. Stewart, and J.R. Bettany. 1982. Cultivation effects on amounts and 395 396 concentration of carbon, nitrogen, and phosphorus in grassland soils. Agron. J. 74:831835.

Tisdall, J.M. and J.M. Oades. 1982. Organic matter and water stable aggregates in soil. J. Soil Sci. 33:141-161.

USDA-NRCS. 1996. Soil quality resource concerns: Compaction. Available at http://urbanext.illinois.edu/soil/sq_info/compact.pdf(accessed 11 Dec. 2009, verified 15 Aug. 2011)

Weil, R.R. and F. Magdoff. 2004. Significance of soil organic matter to soil quality and health. p. 1-43. In F. Magdoff and RR. Weil (ed.) Soil organic matter in sustainable agriculture. CRC Press, Boca Raton, FL.

West, T.O. and W.M. Post. 2002. Soil organic carbon sequestration rates by tillage and crop 406 rotation: A global data analysis. Soil Sci. Soc. Am. J. 66:1930-1946. 
Table 1. Analysis of variance for organic carbon mass, bulk density, water-stable aggregate mass, mean weight diameter, and ponded infiltration rate.

\begin{tabular}{llccc}
\hline Property & & N rate & Tillage & N rate $\times$ Tillage \\
\hline SOC $^{\dagger}$ & $0-5 \mathrm{~cm}$ & $*$ & $*$ & $*$ \\
& $5-10 \mathrm{~cm}$ & $*$ & $\mathrm{~ns}$ & $*$ \\
& $10-15 \mathrm{~cm}$ & $\mathrm{~ns}$ & $\mathrm{~ns}$ & $\mathrm{Ns}$ \\
$\mathrm{BD}^{\ddagger}$ & Total $0-15 \mathrm{~cm}$ & $*$ & $*$ & $\mathrm{Ns}$ \\
& $0-5 \mathrm{~cm}$ & $*$ & $*$ & $\mathrm{Ns}$ \\
& $5-10 \mathrm{~cm}$ & $\mathrm{~ns}$ & $*$ & $\mathrm{Ns}$ \\
$\mathrm{WSA}^{\S}$ & $10-15 \mathrm{~cm}$ & $\mathrm{~ns}$ & $*$ & $\mathrm{Ns}$ \\
& $212-500 \mu \mathrm{m}$ & $\mathrm{ns}$ & $\mathrm{ns}$ & $*$ \\
& $500-1000 \mu \mathrm{m}$ & $\mathrm{ns}$ & $\mathrm{ns}$ & $\mathrm{Ns}$ \\
& $1000-2000 \mu \mathrm{m}$ & $\mathrm{ns}$ & $*$ & $\mathrm{Ns}$ \\
& $2000-4750 \mu \mathrm{m}$ & $*$ & $*$ & $\mathrm{Ns}$ \\
$\mathrm{MWD}^{\Phi}$ & $>4750 \mu \mathrm{m}$ & $*$ & $*$ & Ns \\
Ponded infiltration & -- & $*$ & $*$ & $*$ \\
\hline
\end{tabular}

*Significant, $\alpha=0.05$.

ns: Not significant, $\alpha=0.05$.

$\dagger$ SOC $=$ Soil organic carbon

$\$ \mathrm{BD}=$ Bulk density

${ }^{\$} \mathrm{WSA}=$ Water stable aggregates

ๆ $\mathrm{MWD}=$ Mean weight diameter 
Table 2. Effect of long-term tillage and $\mathrm{N}$ fertilization on soil organic carbon (SOC) mass per area at Manhattan, $\mathrm{KS}^{\dagger}$.

\begin{tabular}{|c|c|c|c|c|c|c|c|c|c|c|}
\hline \multirow[b]{3}{*}{ Depth $(\mathrm{cm})$} & \multicolumn{10}{|c|}{$\mathrm{N}$ fertilization rate $\left(\mathrm{kg} \mathrm{N} \mathrm{ha}^{-1}\right)$} \\
\hline & \multicolumn{2}{|c|}{0} & \multicolumn{2}{|c|}{34} & \multicolumn{2}{|c|}{67} & \multicolumn{2}{|c|}{135} & \multicolumn{2}{|c|}{ Tillage mean $^{\#}$} \\
\hline & NT & $\mathrm{CT}$ & NT & $\mathrm{CT}$ & NT & $\mathrm{CT}$ & NT & $\mathrm{CT}$ & NT & CT \\
\hline & \multicolumn{10}{|c|}{$\longrightarrow \mathrm{Mg} \mathrm{C} \mathrm{ha}^{-1} \longrightarrow$} \\
\hline $0-5$ & $13.1 \mathrm{Ab}^{\ddagger \S}$ & $11.6 \mathrm{Ba}$ & $13.7 \mathrm{Ab}$ & $10.5 \mathrm{Bb}$ & $14.9 \mathrm{Aa}$ & $11.0 \mathrm{Bab}$ & $15.3 \mathrm{Aa}$ & $10.8 \mathrm{Bb}$ & 14.3 & 11.0 \\
\hline $5-10$ & $10.2 \mathrm{Ab}$ & $10.5 \mathrm{Ab}$ & $10.8 \mathrm{Aab}$ & $10.6 \mathrm{Ab}$ & $11.2 \mathrm{Aa}$ & $11.2 \mathrm{Aa}$ & $11.4 \mathrm{Aa}$ & $10.8 \mathrm{Aa}$ & 10.9 & 10.8 \\
\hline $10-15$ & $9.7 \mathrm{Aa}$ & $10.1 \mathrm{Aa}$ & $9.7 \mathrm{Aa}$ & $9.7 \mathrm{Aa}$ & $9.6 \mathrm{Aa}$ & $10.0 \mathrm{Aa}$ & $9.7 \mathrm{Aa}$ & $10.2 \mathrm{Aa}$ & 9.7 & 10.1 \\
\hline Total SOC & \multicolumn{2}{|c|}{$32.6 \mathrm{~B}$} & \multicolumn{2}{|c|}{$32.0 \mathrm{~B}$} & \multicolumn{2}{|c|}{$34.0 \mathrm{~A}$} & \multicolumn{2}{|c|}{$34.1 \mathrm{~A}$} & $34.9 \mathrm{a}$ & $31.7 \mathrm{~b}$ \\
\hline
\end{tabular}

$\dagger \mathrm{CT}=$ conventional tillage; $\mathrm{NT}=$ no-till

$\$$ Within a given depth and $\mathrm{N}$ fertilization rate, uppercase letters represent differences between tillage methods, $\alpha=0.05$.

${ }^{\$}$ Within a given depth and tillage method, lowercase letters represent differences among $\mathrm{N}$ fertilization rates, $\alpha=0.05$.

I Uppercase letters represent differences in total SOC among $\mathrm{N}$ rates when averaged across tillage method, $\alpha=0.05$.

\# Lowercase letters represent differences in total SOC between tillage methods. 
Table 3. Effect of tillage and $\mathrm{N}$ fertilization on bulk density at Manhattan, $\mathrm{KS}^{\dagger}$.

\begin{tabular}{|c|c|c|c|c|c|c|c|c|c|c|}
\hline \multirow[b]{3}{*}{ Depth $(\mathrm{cm})$} & \multicolumn{10}{|c|}{$\mathrm{N}$ fertilization rate $\left(\mathrm{kg} \mathrm{N} \mathrm{ha}^{-1}\right)$} \\
\hline & \multicolumn{2}{|c|}{0} & \multicolumn{2}{|c|}{34} & \multicolumn{2}{|c|}{67} & \multicolumn{2}{|c|}{135} & \multicolumn{2}{|c|}{ Tillage mean } \\
\hline & NT & $\mathrm{CT}$ & NT & $\mathrm{CT}$ & NT & CT & NT & $\mathrm{CT}$ & NT & $\mathrm{CT}$ \\
\hline & & & & & $\mathrm{N}$ & -3 & & & & \\
\hline $0-5$ & 1.29 & 1.46 & 1.28 & 1.35 & 1.28 & 1.36 & 1.26 & 1.35 & $1.28 \mathrm{a}$ & $1.38 \mathrm{~b}$ \\
\hline $5-10$ & 1.42 & 1.53 & 1.44 & 1.50 & 1.46 & 1.56 & 1.42 & 1.48 & $1.44 \mathrm{a}$ & $1.52 \mathrm{~b}$ \\
\hline \multirow[t]{2}{*}{$10-15$} & 1.45 & 1.58 & 1.47 & 1.52 & 1.46 & 1.53 & 1.47 & 1.49 & $1.46 \mathrm{a}$ & $1.53 \mathrm{~b}$ \\
\hline & \multicolumn{8}{|c|}{$\mathrm{N}$ rate comparisons ${ }^{\S}$} & & \\
\hline $0-5$ & \multicolumn{2}{|c|}{$1.38 \mathrm{~B}$} & \multicolumn{2}{|c|}{$1.32 \mathrm{~A}$} & \multicolumn{2}{|c|}{$1.32 \mathrm{~A}$} & \multicolumn{2}{|c|}{$1.32 \mathrm{~A}$} & & \\
\hline $5-10$ & \multicolumn{2}{|c|}{$1.48 \mathrm{~A}$} & \multicolumn{2}{|c|}{$1.47 \mathrm{~A}$} & \multicolumn{2}{|c|}{$1.51 \mathrm{~A}$} & \multicolumn{2}{|c|}{$1.46 \mathrm{~A}$} & & \\
\hline $10-15$ & \multicolumn{2}{|c|}{$1.52 \mathrm{~A}$} & \multicolumn{2}{|c|}{$1.50 \mathrm{~A}$} & \multicolumn{2}{|c|}{$1.50 \mathrm{~A}$} & \multicolumn{2}{|c|}{$1.48 \mathrm{~A}$} & & \\
\hline
\end{tabular}

$\dagger \mathrm{CT}=$ conventional tillage; $\mathrm{NT}=$ no-till

$\$$ Lowercase letters represent differences between tillage methods at a given depth, regardless of $\mathrm{N}$ fertilization rate, $\alpha=0.05$.

$\S$ Uppercase letters represent differences among $\mathrm{N}$ fertilization rates averaged across till 
Fig. 1. Effects of tillage [no-till (NT); conventional till (CT)] and N fertilization on the mass of sand-free water stable aggregates collected on $212,500,1000,2000$, and $4750 \mu \mathrm{m}$ sieves, and mean weight diameter (MWD) at Manhattan, KS. Uppercase letters indicate differences between $\mathrm{N}$ fertilization rates within a tillage method; lowercase letters indicate difference between tillage methods within an $\mathrm{N}$ fertilization a rate $(\alpha=0.05)$.

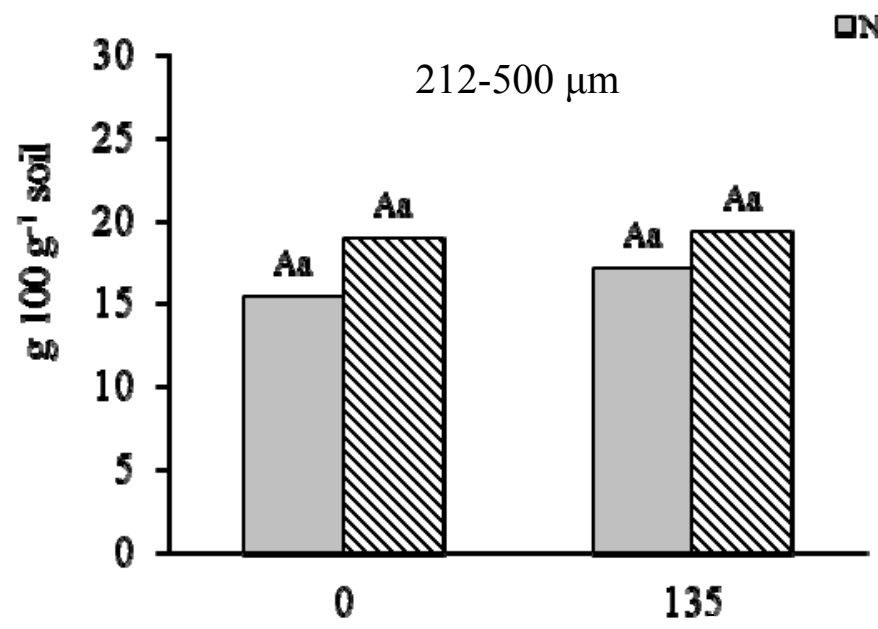

口NT $\triangle C T$
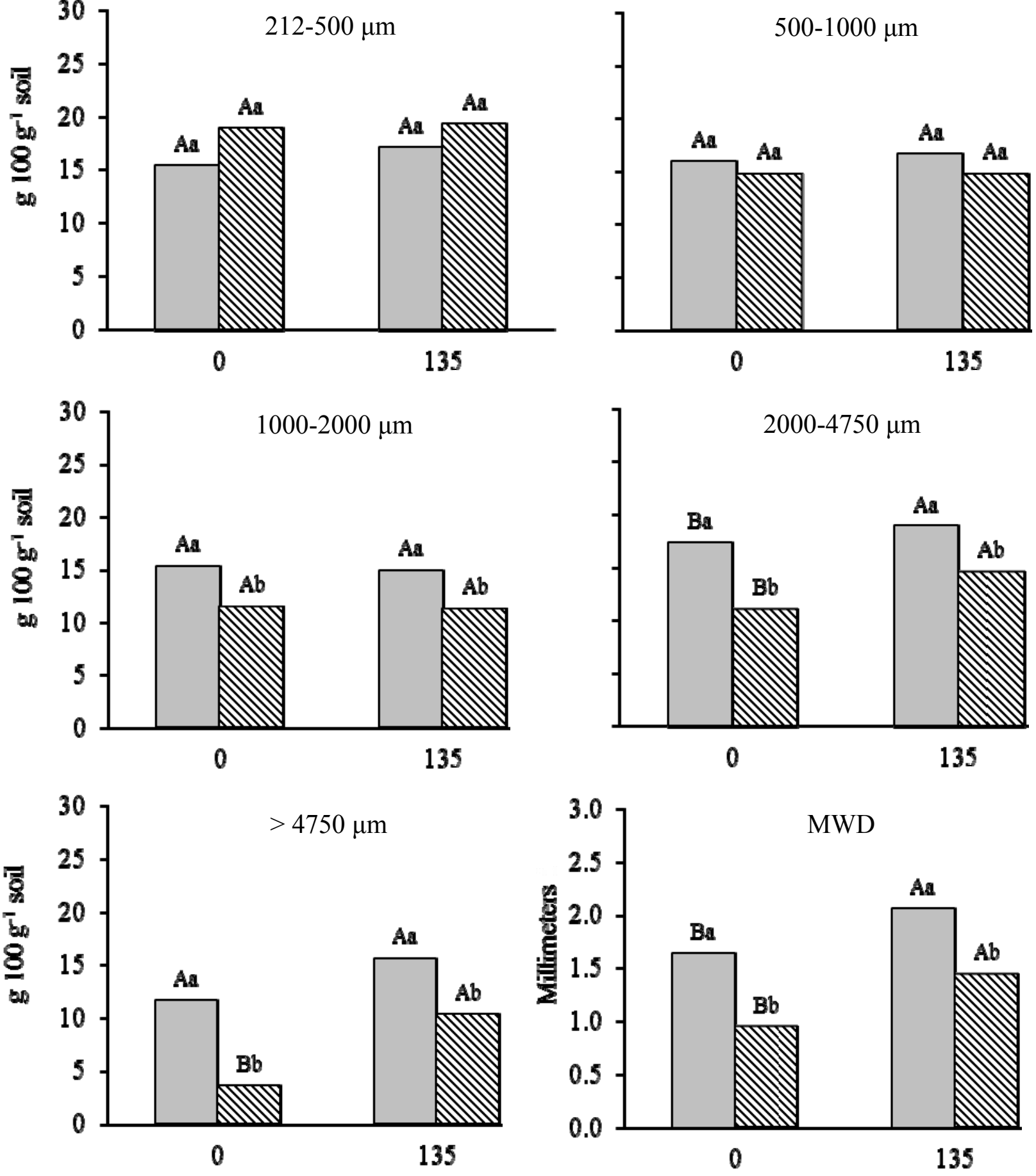

23 
Fig. 2. Linear relationships between (A) mean weight diameter (MWD) and surface 10-cm soil organic carbon (SOC) and (B) MWD and surface 5-cm bulk density at Manhattan, KS.
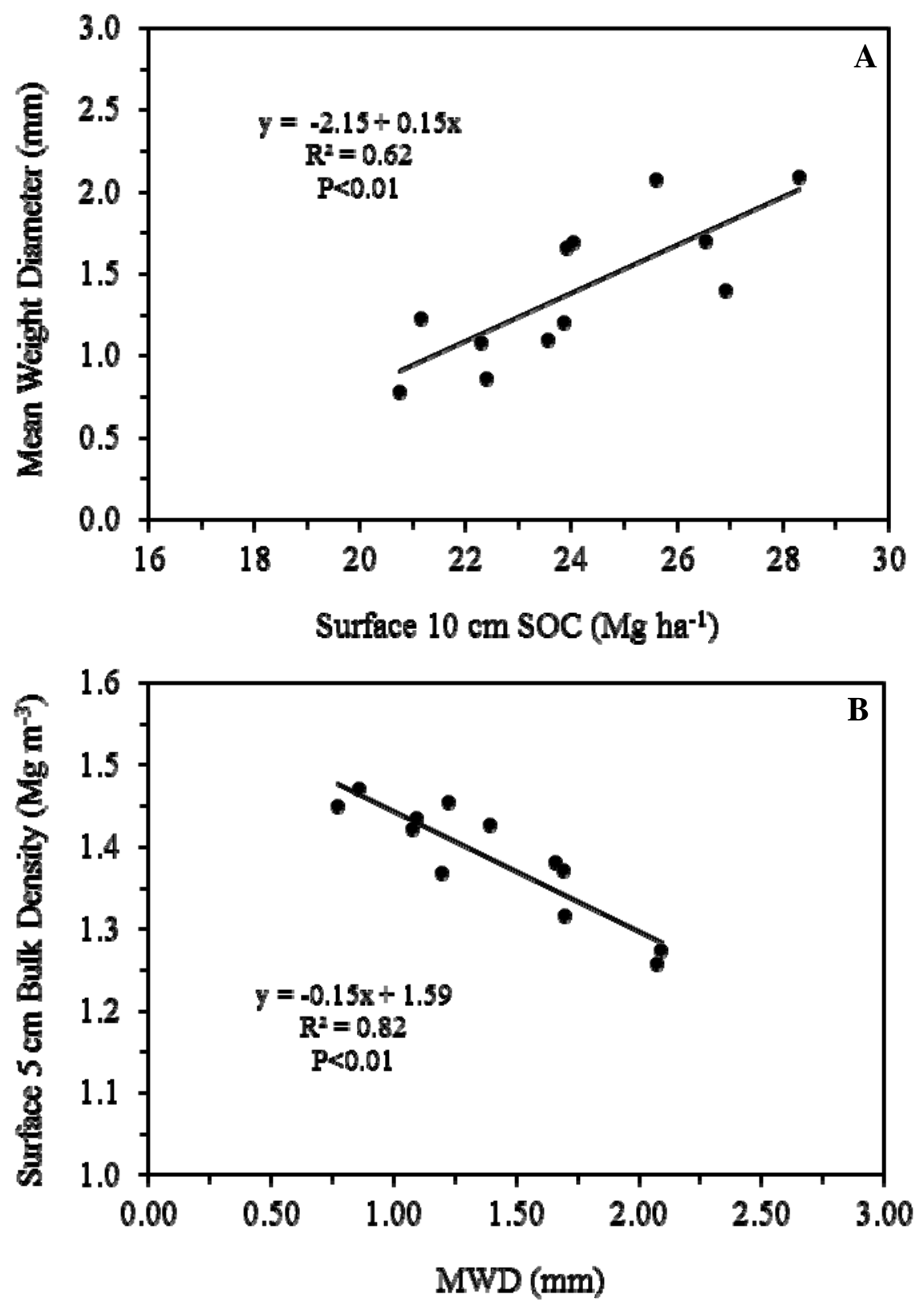
Fig. 3. Effects of tillage [no-till (NT); conventional till (CT)] and N fertilization on ponded infiltration at Manhattan, KS. Uppercase letters indicate differences between $\mathrm{N}$ fertilization rates within a tillage method; lowercase letters indicate difference between tillage methods within a $\mathrm{N}$ fertilization rate $(\alpha=0.05)$.

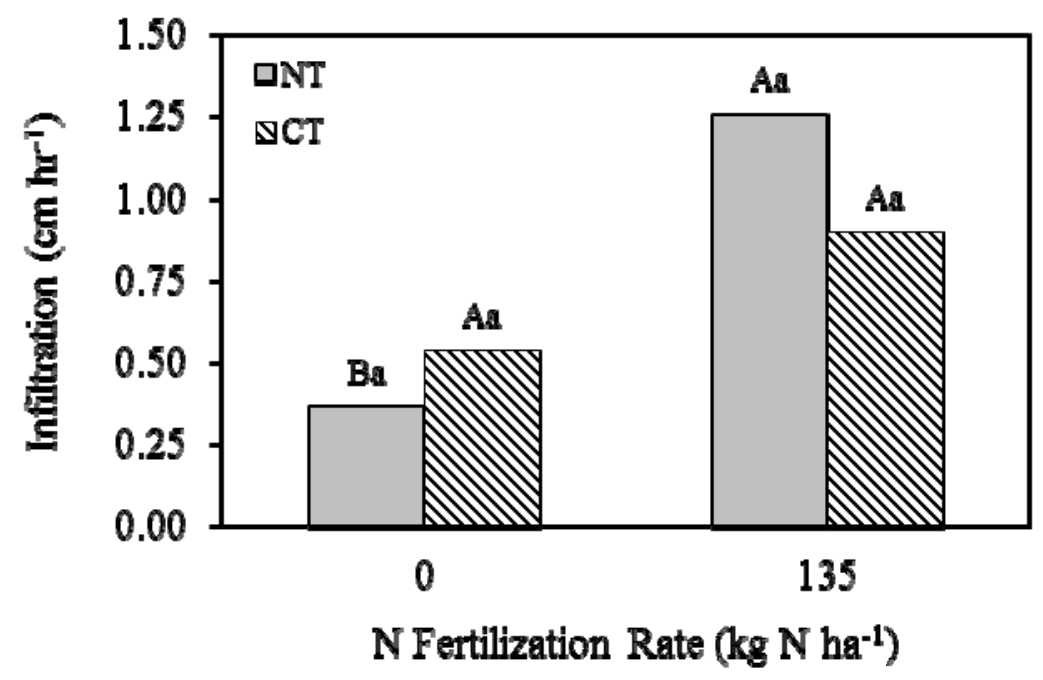

